\title{
Isolation of bacteria from Apis cerana hive, their antibacterial potency and cytotoxicity
}

\author{
YEKKI YASMIN $^{1}$, LENNI FITRI $^{1, \boldsymbol{v}}$, FAUZIAH ${ }^{1}$, FITRI WASLIYAH ${ }^{2}$ \\ ${ }^{1}$ Department of Biology, Faculty of Mathematics and Natural Sciences, Universitas Syiah Kuala.Jl. Syech Abdurrauf No. 3, Kopelma Darussalam, Syiah \\ Kuala, Banda Aceh 23111, Aceh, Indonesia. Tel.: +62-651-7410248, Fax.: +62-651-755138, •email: lennifitri@unsyiah.ac.id. \\ ${ }^{2}$ Biology Program, Faculty of Mathematics and Natural Sciences, Universitas Syiah Kuala. Jl. Syech Abdurrauf No. 3, Kopelma Darussalam, Syiah \\ Kuala, Banda Aceh 23111, Aceh, Indonesia
}

Manuscript received: 18 July 2019. Revision accepted: 29 August 2019.

\begin{abstract}
Yasmin Y, Fitri L, Fauziah, Wasliyah F. 2019. Isolation of bacteria from Apis cerana hive, their antibacterial potency and cytotoxicity. Biodiversitas 20: 2733-2738. This study aimed to identify bacteria from Apis cerana hive; to determine their antibacterial activity, and cytotoxic effect of hive extract as well as bacterial extract. Identification of bacteria isolated from the hive was carried out based on morphological and biochemical characters. The antibacterial assay of beehive bacteria isolates was done by disk diffusion method against Staphylococcus aureus and Escherichia coli. Toxicity test of beehive extract and beehive bacterial extract were carried out using Brine Shrimp Lethality Test (BSLT) with six final concentrations ( 32 ppm, 64 ppm, 126 ppm, 250 ppm, 500 ppm, and 1000 $\mathrm{ppm})$. The $\mathrm{LC}_{50}$ value was determined by probit analysis using SPSS. Bacterial isolation showed there were four bacterial isolates from A. cerana hive were the genus Bacillus (BSL1, and BSL3), the genus Micrococcus (BSL2) and the genus Neisseria (BSL4). The antibacterial assay showed that BSL4 isolate has the highest antibacterial activity against $S$. aureus with the diameter of the inhibitory zone was $32.6 \mathrm{~mm}$. Toxicity test showed that A. cerana hive extract and bacterial ethanol extract from $A$. cerana hive had LC $\mathrm{C}_{50}$ value of $67,744 \mathrm{ppm}$ and $86.985 \mathrm{ppm}$ respectively and categorized as toxic.
\end{abstract}

Keywords: Antibacterial, Apis cerana, BSLT, hive bacteria, $\mathrm{LC}_{50}$

\section{INTRODUCTION}

Apis cerana hive had been studied for its biological activities as antimicrobial, anticancer, antioxidant, antiinflammatory, respiratory tract treatment (Banskota et al. 2001). A. cerana hive can be found on trees in open areas. According to Koetz (2013), bees (A.cerana) could be found nesting in all habitats ranging from primary forests, secondary forests, agricultural areas, residential, and open areas. A.cerana tends to nest at relatively low altitudes, with an average height of one to two meters. Hadisoesilo and Otis (1998) stated that A. cerana had 1-2 cm body length. A. cerana was smaller than Apis dorsata and Apis mellifera which had a body length twice the size of $A$. cerana. Abdominal lines of A. cerana was more prominent than A. mellifera, and worker bee of A. cerana had four abdominal lines, while the worker bee of A. mellifera had three abdominal lines. The tip of A. cerana abdomen was rounded and blunt. According to a study conducted by Damus and Otis (1997), the front wing length of A. cerana was $7.64 \mathrm{~mm}$, the rear wing length was $2.66 \mathrm{~mm}$, and the rear leg length was $6.57 \mathrm{~mm}$.

Beehive is one of the bee products that is widely used for medical purposes. Beehive had mutualistic associations with various types of microbes, namely bacteria, molds, yeasts, and mushroom. This microbial in hive likely to produce secondary metabolites (Promnuan et al.. 2009).
Bioactive compounds produced by microbes are very potential to be developed into drugs. According to Lihan et al. (2014), bacteria, as any other microbes, especially bacteria have the ability to produce biologically active secondary metabolites such as useful antimicrobial.

Many research has been conducted on A. cerana products, but the study on their microbiological analysis was still very limited (Piccini et al. 2004). Piccini and Zunino (2001) reported that Paenibacillus larvae and Melissococcus plutonius was obtained in adult larvae, bee, and honey of A.cerana. Several studies related to bacteria in beehive have been done. Snowdon and Cliver (1996) reported that A. cerana microbes were commonly found in beehive and adult bee. Another study discovered 32 actinobacteria isolated from the beehives of three species of Apis spp. and two stingless bee species in Thailand. These actinobacteria were capable of producing antibacterial compounds against pathogenic bacteria $P$. larvae and $M$. plutonius in A. cerana (Promnuan et al. 2009). Therefore, bacteria from beehive had the potential as natural antimicrobial sources which might be able to overcome the problem of resistance from commercial antimicrobials.

Therefore, it is necessary to conduct a study to determine the antimicrobial activity produced by bacteria isolated from A. cerana hive. This study aimed to isolate and determine the antibacterial activity and cytotoxicity of bacteria isolated from the beehive. 


\section{MATERIALS AND METHODS}

\section{Isolation of beehive bacteria}

One gram of hive was soaked with sterile distilled water for one minute, then the surface was soaked with $70 \%$ alcohol for three minutes and soaked again with sterile distilled water for one minute. Furthermore, the beehive was cut using a sterile knife and mashed using mortar and pestle, then added with $5 \mathrm{~mL}$ of sterile distilled water and homogenized using vortex for three minutes. A total of 100 $\mu \mathrm{L}$ of the suspension was taken out using a micropipette and spread onto nutrient agar (NA) medium. The sample was incubated at $37^{\circ} \mathrm{C}$ for 48 hours (Promnuan et al. 2009).

\section{Bacteria identification}

Bacterial identification was conducted by selecting several bacteria colonies that showed differences in agar medium. Identification was conducted by referring to Bergey's Manual of Determinative Bacteria (Holt et al 1994) and the Manual for the Identification of Medical Bacteria (Cowan and Steels 1993).

\section{Antibacterial activity test}

Staphylococcus aureus and Escherichia coli were used for the antibacterial assay. S. aureus and E. coli were incubated for 24 hours at $37^{\circ} \mathrm{C}$ in slanted NA medium. After incubation complete, S. aureus and E. coli were picked using an inoculating loop and suspended into $0.9 \%$ $\mathrm{NaCl}$ solution. Furthermore, $1 \mathrm{~mL}$ of bacterial suspension was taken out and spread on the surface of sterilized MHA medium and left for 5 minutes.

Beehive bacteria isolates were taken using cork borer and transferred onto Mueller Hinton Agar (MHA) medium; the isolates were put upside down facing the media that has been inoculated with tested bacteria. Each isolate was tested with three replication (triplicate). The agar plates were incubated at room temperature for 24 hours (Pratiwi 2008). Antibacterial activity was carried out in triplicate and determined by measuring the diameter of the clear zone or inhibitory zone formed using a caliper.

\section{Toxicity test}

\section{Preparation of beehive ethanol extract}

A total of 500 beehives was cut into small pieces and dried using an oven at $50^{\circ} \mathrm{C}$. The dried sample was crushed with blender, then macerated with $70 \%$ ethanol for $3 \times 24$ hours. The ethanol extract was dried and concentrated with a rotary evaporator at $50^{\circ} \mathrm{C}$. A stock solution of beehive ethanol extract was prepared at a concentration of 2000 $\mathrm{ppm}$. Seawater was added into $20 \mathrm{mg}$ beehive ethanol extract until the volume reached $10 \mathrm{~mL}$ to make the solution at a concentration of $2000 \mathrm{ppm}$.

\section{Preparation of bacteria ethanol extract}

Bacteria with the highest antibacterial activity (BSL4) was inoculated into $50 \mathrm{~mL}$ of Nutrient Broth medium in Erlenmeyer and incubated in a shaker incubator at $150 \mathrm{rpm}$ for two days at room temperature. Cells were separated by centrifugation at $6000 \mathrm{rpm}$ for 30 minutes; then the supernatant was collected and added with ethanol $(1: 1 \mathrm{v} / \mathrm{v})$ and homogenized until two layers were formed. The solvent fraction was concentrated using rotary evaporator at $50^{\circ} \mathrm{C}$.

\section{Brine Shrimp Lethality Test (BSLT)}

Six concentrations of extract with the concentrations of $1000 \mathrm{ppm}, 500 \mathrm{ppm}, 250 \mathrm{ppm}, 126 \mathrm{ppm}, 64 \mathrm{ppm}$ and 32 ppm were prepared by pipetting respectively $2500 \mu \mathrm{L}$, $1250 \mu \mathrm{L}, 625 \mu \mathrm{L}, 315 \mu \mathrm{L}, 160 \mu \mathrm{L}$, and $80 \mu \mathrm{L}$ of stock solution into test tubes and added with $2 \mathrm{~mL}$ seawater, 10 larvae of brine shrimp and seawater was added again until the volume of each tube reaching $5 \mathrm{~mL}$. The number of dead larvae was counted after 24 hours. Total mortality was obtained by summing the dead larvae in each concentration. Each sample was tested with three replications (triplicate). The control was conducted with the same method as the sample without adding crude extract. Negative control was contained only larvae of brine shrimp and seawater (Kumala and sapitri et al. 2011).

\section{Data analysis}

Data from the results were analyzed descriptively presented in the form of tables and images, and the LC50 value was analyzed by probit analysis using SPSS Statistics 23.0.

\section{RESULTS AND DISCUSSION}

\section{Isolation of bacteria from the beehive}

By culturing A. cerana hive on NA medium, it was found a total of 4 bacteria isolates from A. cerana hive. The results of previous studies showed a different number of bacteria isolates. Promnuan et al. (2009) reported one isolate from A. florea hive, two isolates from A. cerana hive, eight isolates from A. mellifera hive, eight isolates from stingless bee Trigona laeviceps hive, and four isolates from stingless bee Trigona fuscobalteata hive. Gilliam et al. (1990) reported three bacteria isolates from stingless bee Melipona fasciata hive, while Piccini et al. (2004) reported 16 bacteria isolates from 12 Apis sp. hives.

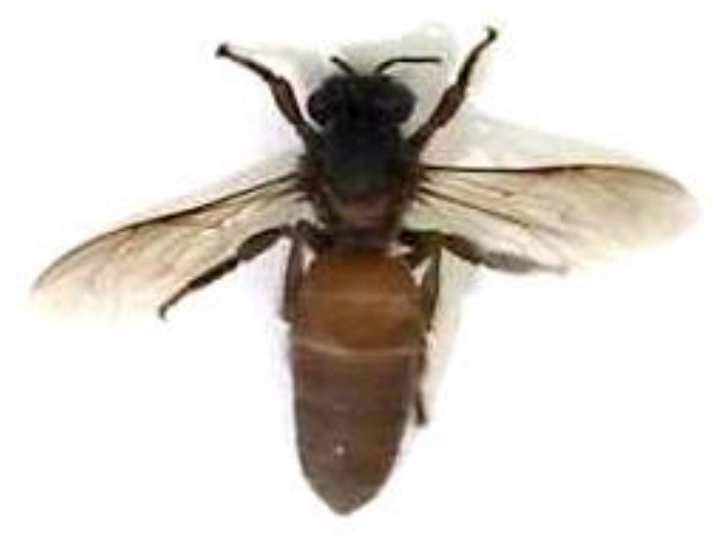

Figure 1. Apis cerana 
The number of bacteria obtained from beehive was influenced by several factors. According to Promnuan et al. (2009), the factor that influences the number of bacteria to isolate was the geographical or environmental location of the beehive. Bacteria enter the hive through worker bees that collect food or water from the environment outside the hive. Plants that were used as food sources and raw materials for making a hive for each bee was different depending on the environment around the hive. Therefore, the number of bacteria species in each beehive was varied.

\section{Morphological and physiological characteristics of $A$. cerana Beehive bacteria}

Characterization of bacterial isolates was conducted macroscopically and microscopically. Macroscopic characterization was carried out by observing morphological characters of bacteria colonies, i.e., colony form, margin, color, and elevation (Figure 2). The morphology of bacterial isolates presented in Table 1 .

Based on the observations, bacteria isolates had different colony forms, margins, colors, and elevations. Morphological characterization of bacteria was carried out based on Prescott's Microbiology (2002). According to Prescott et al. (2002), bacteria that cultured on agar medium would form a colony with different patterns. This pattern varied due to the ability of bacteria to absorb nutrients from the agar medium.

Microscopic characterization was carried out by Gram staining, to observe bacteria cell form and to differentiate bacteria into Gram-positive and Gram-negative bacteria. The results of Gram staining presented in Table 2.

Based on Gram staining (Figure 3), BSL1, BSL2, and BSL3 isolates belonged to Gram-positive bacteria, while BSL4 belonged to Gram-negative bacteria. Based on the observations, it was shown that BSL1 Gram-positive coccobacilli form, BSL2 was Gram-positive coccus form, BSL3 was Gram-positive rod/bacilli, and BSL4 was Gramnegative coccus form.

Table 1. Morphology of bacteria isolated from Apis cerana beehive

\begin{tabular}{lllll}
\hline \multirow{2}{*}{ Isolate } & \multicolumn{4}{c}{ Morphology } \\
& Colony form & Margin & Color & Elevation \\
\hline BSL1 & Filamentous & Thread-like & White & Flat \\
BSL2 & Circular & Smooth & Milky white & Convex \\
BSL3 & Filamentous & Thread-like & White & Flat \\
BSL4 & Circular & Smooth & White & Raised \\
\hline
\end{tabular}

Note: BSL: bacteria isolated from the beehive

Table 2. Gram staining of Apis cerana hive bacteria

\begin{tabular}{llcc}
\hline Isolate & Cell form & \multicolumn{2}{c}{ Gram staining } \\
\cline { 2 - 4 } & & $\begin{array}{c}\text { Positive } \\
\text { (violet) }\end{array}$ & $\begin{array}{c}\text { Negative } \\
\text { (pink/red) }\end{array}$ \\
\hline BSL1 & Coccobacilli & + & \\
BSL2 & Coccus & + & \\
BSL3 & Rod/bacilli & + & + \\
BSL4 & Coccus & & + \\
\hline
\end{tabular}

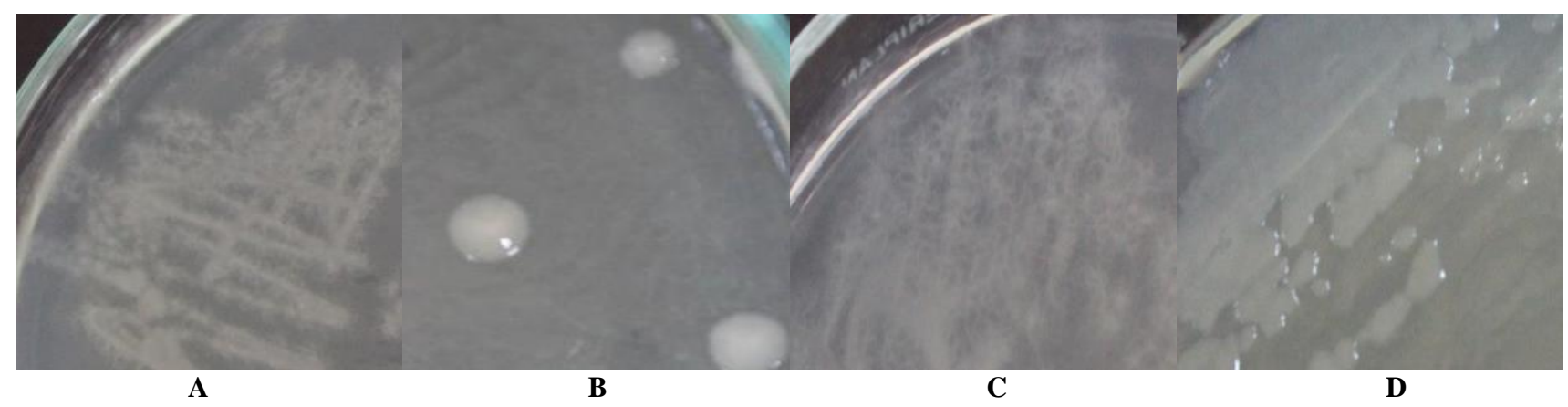

Figure 2. Macroscopic morphology of bacteria isolated from the beehive on NA medium. A. BSL1, B. BSL2, C. BSL3, D. BSL4

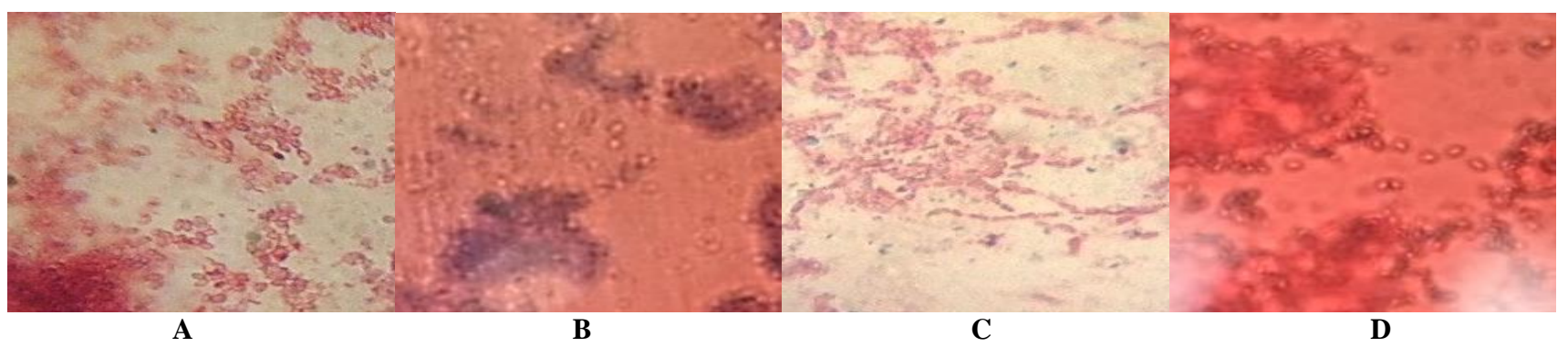

Figure 3. Gram staining of Apis cerana hive bacteria. A. BSL1, B. BSL2, C. BSL3, D. BSL4 
Table 3. Biochemical properties of Apis cerana hive bacteria

\begin{tabular}{lcccc}
\hline \multirow{2}{*}{ Test } & \multicolumn{4}{c}{ Isolate } \\
\cline { 2 - 5 } & BSL1 & BSL2 & BSL3 & BSL4 \\
\hline Catalase & + & + & - & + \\
Motility & + & - & + & - \\
Indole & - & - & - & - \\
MR & - & - & + & - \\
Simmons citrate & - & + & - & + \\
TSIA: & & & & \\
Glucose & + & + & + & + \\
Glucose dan sucrose & - & - & - & - \\
$\mathrm{H}_{2} \mathrm{~S}$ & - & - & - & - \\
Gas & - & - & + & - \\
\hline
\end{tabular}

Table 4. The inhibitory zone of bacteria isolated from Apis cerana hive against Staphylococcus aureus and Escherichia coli

\begin{tabular}{lcc}
\hline Isolate & \multicolumn{2}{c}{ Mean of inhibition zone $(\mathbf{m m})$} \\
\cline { 2 - 3 } & S. aureus & $\boldsymbol{E}$ coli \\
\hline BSL1 & 13,8 & 0 \\
BSL2 & 14,05 & 0 \\
BSL3 & 0 & 0 \\
BSL4 & 32,6 & 0 \\
\hline
\end{tabular}

Biochemical test of $A$. cerana hive bacteria was carried out to identify bacteria isolated from the beehive. The biochemical test included catalase, motility, indole, Methyl Red (MR), Simmons Citrate, and TSIA test. Biochemical test of bacteria from beehive presented in Table 3 .

Identification of bacteria isolated from beehive based on bacteria characteristics was carried out according to the Bergey's Manual of Determinative Bacteria (Holt et al. 1994) Isolates of BSL1 and BSL3 have the characteristics of the genus Bacillus. According to Holt et al. (1994), Bacillus is a genus of Gram-positive bacteria. Bacillus species showed a very broad range of colonial morphologies, affected by medium composition and incubation conditions. The colonies of the genus Bacillus were characteristically large (2-7 $\mathrm{mm}$ in diameter) and vary in shape from round to irregular. The surface is matt or granular textures, but the colonies were commonly smooth, moist, shiny, slimy, sometimes spread out and covered the entire surface. The elevation was flat, raised, and convex. The colors generally ranged from pale, gray or white, and occasionally produce black, brown, orange, pink or yellow pigment. The pigment produced by bacterial colony tends to be the characteristic of a species or subspecies.

Based on the characteristics of BSL2 isolate, it was identified as the genus Micrococcus. According to Cowan and Steels (1993), Colony of the genus Micrococcus was yellow or cream-colored, round shape, and raised colony margin. The cell was round and forming a pair, four pairs, or a non-fixed group that does not form chains, with a diameter of 0.5-2.0 $\mu \mathrm{m}$, Gram-positive, not motile, positive catalase, negative oxidase, positive methyl red, no spore, did not produce acid, and the optimum growth temperature was from $30-37^{\circ} \mathrm{C}$. Micrococcus sp. could be found in mammalian skin and soil, but usually isolated from food products and the air.

Based on the characteristics, BSL4 has the characteristics of the genus Neisseria. According to Holt et al. (1994), the genus Neisseria are Gram-negative bacteria in the form of cocci, generally not motile, does not produce acid and negative indole. The genus Neisseria has a broad range of environments; it could be found in the human body, water, soil, and air.

Previous studies showed that various species of the genus Bacillus had been isolated from a stingless beehive (Gilliam et al. (1990) and from Apis sp. hive (Piccini et al. 2015). Promnuan et al. (2009) reported several bacteria that commonly found in the soil were also found in a beehive. According to Piccini et al. (2015), plants around the hive were used as food sources and raw materials for making the hive. Therefore it was very likely to find various types of bacteria in A. cerana hive.

\section{Antibacterial activity test}

Antibacterial activity test was carried out by observing and measuring the diameter of the inhibitory zone of bacteria isolated from A. cerana hive against Staphylococcus aureus and Escherichia coli. The results were presented in Table 4.

BSL1, BSL2, and BSL4 isolates were able to inhibit the growth of S.aureus with the diameter of the inhibitory zone were $13.8 \mathrm{~mm}, 14.05 \mathrm{~mm}$, and $32.6 \mathrm{~mm}$, respectively. Gupte (2010) stated that that the diameter of the inhibitory zone indicated bacteria sensitivity to the antibacterial agents. BSL1 and BSL2 have strong antibacterial activity, whereas BSL4 has very strong antibacterial activity based on the antibacterial categories by Davis and Stout (1971). According to Davis and Stout (1971) the antibacterial potency categorized based on the diameter of the inhibitory zone as follows: very strong (>20 mm), strong (sensitive) (10-20 mm), intermediates (5-10 mm), and weak (resistant) (<5 mm). Dharmawan et al. (2009) stated that the inhibitory zone was varied for different species because every species produces different secondary metabolites and different concentrations of secondary metabolites.

BSL1, BSL2, and BSL4 were able to inhibit the growth of Gram-positive bacteria ( $S$. aureus) but were unable to inhibit the growth of Gram-negative bacteria ( $E$. coli). It was assumed due to the structural differences of the bacterial cell wall. Bacteria cell walls determined the characteristics and primary function to protect the inside of the cell. The cell wall of Gram-negative bacteria consists of several layers, while Gram-positive bacteria have a relatively simpler cell wall structure than Gram-negative bacteria. The gram-positive cell wall is composed of relatively thick peptidoglycan layer, surrounded by teichoic acid and in some species has polysaccharide. The gramnegative cell wall has a relatively thin layer of peptidoglycan, surrounded by a lipoprotein, lipopolysaccharide, phospholipid, and some proteins (Hardy 2002). 


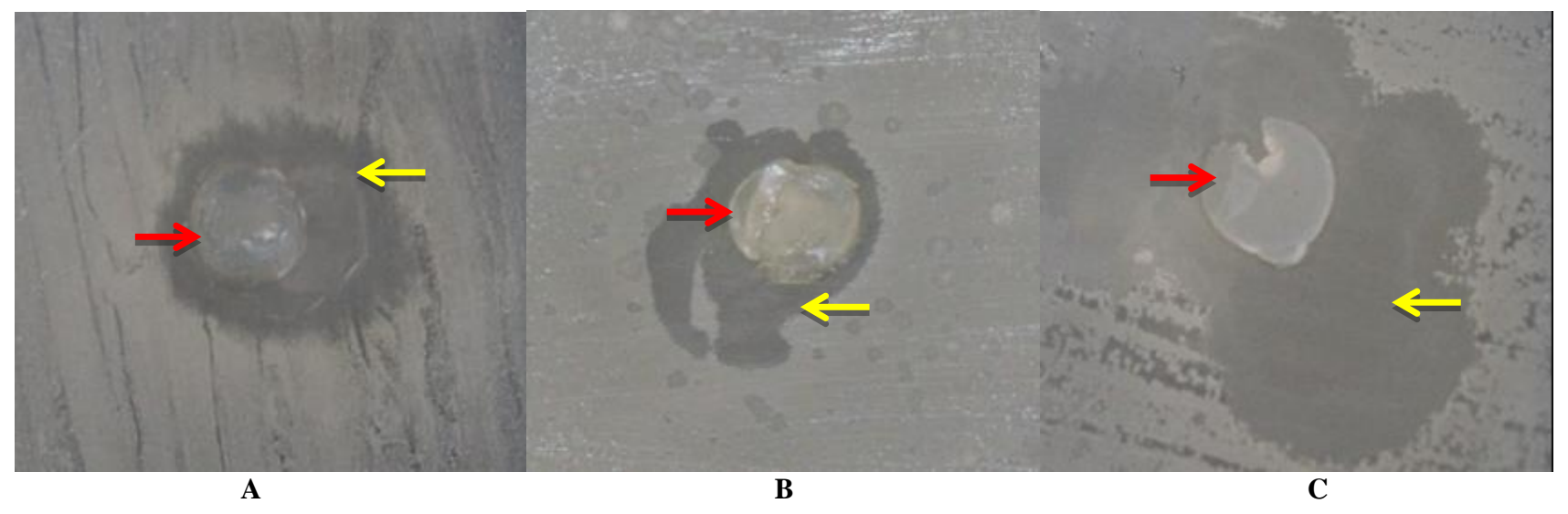

Figure 4. Inhibitory zone of Apis cerana hive bacteria against Staphylococcus aureus. A. BSL1; B. BSL2; C. BSL4. Note: $\longrightarrow$ : Bacteria isolate; $\stackrel{\Rightarrow}{\rightleftharpoons}$ Inhibitory zone

Staphylococcus aureus is a Gram-positive bacteria with thick cell walls consist of peptidoglycan. According to Brooks et al. (2013), peptidoglycan is a component that determines cell wall flexibility at Gram-positive and plays a role in Gram-positive integrity. The antibacterial activity is more susceptible to Gram-positive bacteria because the outer membrane of the cell wall is only protected by peptidoglycan so that more accessible to antibiotic molecules. Gram-negative bacteria contain lipopolysaccharide on the outer membrane result in the bacteria to be more resistant to certain types of antibiotics, while Gram-positive bacteria are more susceptible to antibiotics.

\section{Toxicity test of Apis cerana hive bacteria: Brine Shrimp Lethality Test (BSLT)}

Toxicity tests were carried out on beehive extract, and bacteria extract using Brine Shrimp Lethality Test (BSLT). Beehive and beehive bacteria were extracted using ethanol because it has high polarity so that they can extract more chemical compounds compared to other organic solvents. Ethanol also has a low boiling point, tends to be safe or non-toxic (Gamse 2002). According to Meyer et al. (1982), BSLT was carried out by observing the mortality rate of brine shrimp larvae after treating with the extract. Toxic compounds cause high mortality. Mardany et al. (2016) stated that mortality in Artemia salina larvae caused by toxic compounds that enter the body, resulting in changes in concentration inside and outside the cell. After these toxic compounds enter orally and dermally, and absorbed into the tissues and attack cells, followed by functional and metabolic damage. The effect occurs quickly within 24 hours because $A$. salina had a very thin skin membrane so that it allows diffusion of substances from the environment. Furthermore, Mardany et al. (2016) stated that the growth phase of shrimp larvae used in BSLT was the nauplius phase as being the most active phase.

The results showed that the mortality rate of $A$. salina larvae treated with beehive and bacteria isolated from beehive after 24 hours in various concentrations was shown in Table 5.
Table 5. The mortality rate of Artemia salina larvae treated with beehive and bacteria isolated from beehive extract

\begin{tabular}{lcc}
\hline \multirow{2}{*}{ Concentration } & \multicolumn{2}{c}{ \% Mortality } \\
\cline { 2 - 3 } & $\begin{array}{c}\text { Beehive } \\
\text { ethanol extract }\end{array}$ & $\begin{array}{c}\text { Bsl4 } \\
\text { ethanol extract }\end{array}$ \\
\hline 0 & 0 & 0 \\
32 & 15 & 10 \\
64 & 55 & 50 \\
126 & 75 & 60 \\
250 & 95 & 85 \\
500 & 95 & 95 \\
1000 & 100 & 100 \\
\hline
\end{tabular}

The extracts of beehive and bacteria isolated from beehive result in brine shrimp larval death, increasing concentration of extract results in an increased mortality rate. The highest mortality occurred in extracts with a concentration of $1000 \mathrm{ppm}$, while the lowest mortality percentage was at $32 \mathrm{ppm}$, negative control treatment/ without extract did not result in larval death. Based on the probit analysis by SPSS it showed that the $\mathrm{LC}_{50}$ value of $A$. cerana hive extract was $67,744 \mathrm{ppm}$ and $\mathrm{LC}_{50}$ value of $A$. cerana hive bacteria extract was $86,985 \mathrm{ppm}$. It showed that bioactive compounds in beehive were more toxic than bioactive compounds produced by BSL4. A study by Thamrin et al. (2016) showed that the $\mathrm{LC}_{50}$ value of Trigona incisa hive ethanol extract was $355.46 \mathrm{ppm}$. Secondary metabolites of extracts affected $\mathrm{LC}_{50}$ value.

Meyer et al. (1982) stated that the higher the concentration of toxic secondary metabolites, the smaller the $\mathrm{LC}_{50}$ value. Toxicity level of extract categorized as follows: $\mathrm{LC}_{50} \leq 30 \mathrm{ppm}=$ Very toxic; $31 \mathrm{ppm} \leq \mathrm{LC}_{50} \leq$ $1000 \mathrm{ppm}=$ Toxic, $\mathrm{LC}_{50}>1000 \mathrm{ppm}=$ Not toxic. It showed that ethanol A. cerana hive extract of and A. cerana hive bacteria extracts were categorized as toxic. 


\section{ACKNOWLEDGEMENTS}

The author would like to thank the Ministry of research, Technology and higher education for the financial support through Basic Research Funding fiscal year 2019 (Contract No.: 215/SP2H/LT/DPRM/2019).

\section{REFERENCES}

Banskota AH, Tezuka Y, Kadota S. 2001. Recent progress in pharmacological research of propolis. Phytother Res 15: 561-571.

Brooks GF, Carrol KC, Butel JS, Morse SA, Mietzner TA. 2013. Jawetz, Melnick \& Adelberg's Medical Microbiology. 26th ed. McGraw-Hi II Co. , United States.

Cowan ST, Steel KJ. 1993. Manual for The Identification of Medical Bacteria. 3rd ed. Cambridge University Press, London.

Damus MS, Otis GW. 1997. A morphometric analysis of Apis cerana F and Apis nigrocincta Smith populations from Southeast Asia. Apidologie 28: 309-323.

Davis WW, Stout TR. 1971. Disc plate method of microbiological antibiotic assay. Appl Microbiol 22 (4): 659-665.

Dharmawan IWE, Retno K, Made SP. 2009. Isolation of Streptomyces spp. in Bali Barat National Park and inhibition test to five diarrheagenic Escherichia coli strain. Jurnal Biologi 13 (1): 1-6. [Indonesian].

Gamse T. 2002. Liquid-Liquid Extraction and Solid-Liquid Extraction. Institute of Thermal Process and Environmental Engineering, Graz University of Technology, Austria.

Gupte S. 2010. Short Text Book of Medical Microbiology, 10th ed. Jaypee Brothers Medical Publishers (P) Ltd., New Delhi.

Gilliam M, Roubik DW, Lorenz BJ. 1990. Microorganisms associated with pollen, honey, brood provisions in the nest of a stingless bee, Melipona fasciata. Apidologie 21: 89-97.

Hadisoesilo S, Otis GW. 1998. Differences in drone cappings of Apis cerana and Apis nigrocincta. J Apicult Res 37 (1): 11-15.

Hardy PS. 2002. Human Microbiology. CRC Press, London.
Holt JG, Krieg NR, Sneath PHA, Staley JT, William ST. 1994. Bergey’s Manual of Determinative Bacteriology. 9th ed. William and Wilkins, Baltimore.

Koetz AH. 2013. Ecology, behaviour, and control of Apis cerana with a focus on relevance to the Australian incursion. Insects 4: 558-592.

Kumala S, Sapitri DW. 2011. Phytochemical screening and toxicological evaluation using Brine Shrimp Lethality Test (BSLT) of some fractions of prasman leaves (Eupatorium triplinerve V) extract. Indone J Cancer Chemoprev 2 (1): 194-197.

Lihan S, Lin CS, Ahmad I, Sinang FM, Hua NK, Sallehin AA. 2014. Antimicrobial producing microbes isolated from soil samples collected from Nanga Merit Forest in Sarawak, Malaysian Borneo. Eur J Exp Biol 4 (1): 494-501.

Mardany MP, Chrystomo LY, Karim AK. 2016. Phytochemical screening and cytotoxic activity test of the semut sarang plant (Myrmecodia beccarii Hook.f.) origin of Merauke District. Jurnal Biologi Papua 8 (1): 13-22. [Indonesian]

Meyer BN, Ferrigni NR, Putnam JE, Jacobson LB, Nichols DE, McLaughlin JL. 1982. Brine Shrimp: A convenient general bioassay for active plant constituents. Planta Medica 45: 31-34.

Piccini C, Zunino P. 2001. American foulbrood in Uruguay: Isolation of Paenibacillus larvae subspecies larvae from larvae with clinical symptoms and adult honeybees, and susceptibility to oxytetracycline. J Invertebr Pathol 78: 176-177.

Piccini C, Antunez K, Zunino P. 2004. An approach to the characterization of the honey bee hive bacterial flora. J Apicult Res 43 (3): 101-104.

Prescott LM, Harley, Klein. 2002. Microbiology. 5th ed. McGraw-Hill, New York.

Pratiwi ST. 2008. Pharmaceutical Microbiology. Erlangga, Jakarta. [Indonesian].

Promnuan Y, Kudo T, Chantawannakul P. 2009. Actinomycetes isolated from beehives in Thailand. World J Microbiol Biotechnol 25: 16851689.

Snowdon JA, Cliver DO. 1996. Microorganisms in honey. Intl J Food Microbiol 31: 1-26.

Thamrin A, Erwin, Syafrizal. 2016. Phytochemical test, toxicity and antioxidant of Incolis trigona bee honey propolis extract with 2,2diphenyl-1-picrylhydrazyl (DPPH) method. Mulawarman Chem J 14 (1): 54-60. [Indonesian] 